\title{
Controlled Decompression for the Treatment of Severe Head Injury: A Preliminary Study
}

\author{
Siddetli Kafa Travmasnnm Tedavisinde Kontrollü Dekompresyon: \\ Bir Ön Çalışma
}

Yuhai WANG, Chunli WANG, Likun YANG, Sang CAI, Xuejian CAI, Jirong DONG, Jiandong ZHANG, Jun ZHU 101 Hospital of Chinese People's Liberation Army, Department of Neurosurgery, XingYuan North Road, Wu Xi, Jiang Su, China

Corresponding Author: Yuhai WANG / E-mail: dryuhaiwang@yeah.net, wangyuhai67@126.com

\begin{abstract}
AIM: Fast direct decompression surgery for treatment of severe head injury often results in intraoperative and postoperative complications. Controlled decompression may help prevent these complications. This preliminary study aims to compare the effects of controlled and conventional decompression in patients with severe head injury.

MATERIAL and METHODS: A total of 128 patients with severe head injury were included. Patients were allocated to receive either controlled decompression surgery $(n=64)$ or conventional decompressive craniectomy $(n=64)$. Controlled decompression comprised controlled ventricular drainage and controlled hematoma evacuation. The occurrence of delayed hematoma, acute brain swelling, and postoperative cerebral infarction were recorded.

RESULTS: Significantly lower proportion of patients in the controlled decompression group had intraoperative acute brain swelling compared to patients in the decompressive craniectomy group $(9.4 \%$ vs $26.6 \%, P=0.011)$. Intraoperative acute encephalocele occurred in 3 of 13 patients (23.1\%) who had delayed hematoma in the controlled decompression group compared with 11 of 18 patients (61.1\%) in the decompressive craniectomy group. There was no significant between group difference in the incidence of delayed hematoma or postoperative cerebral infarction.
\end{abstract}

CONCLUSION: Controlled decompression may reduce or delay intraoperative acute brain swelling by delaying hematoma formation in patients with severe head injury.

KEYWORDS: Brain swelling, Decompressive craniectomy, Severe, Head injury, Traumatic intracranial hematoma

\section{Öz}

AMAÇ: Şiddetli kafa travmasının hızlı ve doğrudan dekompresyon cerrahisi sıklıkla intraoperatif ve postoperatif komplikasyonlara neden olur. Kontrollü dekompresyon bu komplikasyonları önlemeye yardımcı olabilir. Bu ön çalışma, şiddetli kafa travması olan hastalarda kontrollü ve geleneksel dekompresyonun etkilerini karşılaştırmayı amaçlamaktadır.

YÖNTEM ve GEREÇLER: Şiddetli kafa travması olan toplam 128 hasta dahil edilmiştir. Hastalar kontrollü dekompresyon cerrahisi $(\mathrm{n}=64)$ veya geleneksel dekompresif kraniyektomi $(n=64)$ yapılacak şekilde ayrılmışlardır. Kontrollü dekompresyon grubunda kontrollü ventriküler drenaj ve kontrollü hematom boşaltılması yapılmıştır. Gecikmiş hematom, akut beyin şişmesi ve postoperatif serebral enfarktüs oluşması kaydedilmiştir.

BULGULAR: Kontrollü dekompresyon grubundaki hastalarda intraoperatif akut beyin şişmesi yüzdesi dekompresif kraniyektomi grubundan önemli ölçüde daha düşük olmuştur $(\% 9,4$ ve $\% 26,6, P=0,011)$. Intraoperatif akut ensefalosel, kontrollü dekompresyon grubunda gecikmiş hematomu olan 13 hastanın 3'ünde $(\% 23,1)$ görülürken dekompresif kraniyektomi grubunda 18 hastanın 11'inde (\%61,1) görülmüştür. Gecikmiş hematom veya postoperatif serebral enfarktüs insidansı açısından gruplar arasında önemli bir fark görülmemiştir.

SONUÇ: Kontrollü dekompresyon şiddetli kafa travmalı hastalarda hematom oluşumunu geciktirerek intraoperatif akut beyin şişmesini azaltabilir veya geciktirebilir.

ANAHTAR SÖZCÜKLER: Beyin şişmesi, Dekompresif kraniyektomi, Şiddetli kafa travması, Travmatik intrakraniyal kanama

\section{INTRODUCTION}

Diffuse brain swelling, intraoperative acute encephalocele, and postoperative cerebral infarction are the most important factors that affect prognosis in patients with severe head injury who require surgery to relieve increased intracranial pressure (ICP) (3). Indeed, there is evidence to suggest that the associated rates of mortality and severe disability in these patients are between $50 \%$ and $70 \%(16,17)$. Hence optimizing surgical techniques to alleviate increased ICP and prevent intraoperative acute encephalocele and postoperative cerebral infarction remains a key issue and a critical challenge in neurosurgery.

Decompressive craniectomy is a common means of rapidly reducing ICP in patients with severe head injuries (14). 
Although this approach has been reported to effectively reduce ICP and improve prognoses in some studies $(1,2,7,8)$, the findings from a recent multinational randomized trial indicate that decompressive craniectomy may be associated with worse outcomes, as indicated by 6-month extended Glasgow Outcome Scale (GOS) scores, compared with standard care in patients with severe head injury (2). The authors of the report suggested that neural injury and alterations in cerebral blood flow and metabolism may have contributed to the worse outcome with decompressive craniectomy (2). We suggest that the rapid release of ICP with this surgical approach may result in ischemia-reperfusion injury and further bleeding. Regardless of the underlying mechanisms, alternative approaches for relieving ICP in patients with severe head injury appear to be needed.

Controlled decompression is a form of craniotomy whereby ICP is gradually released (as opposed to rapidly released with standard decompressive craniectomy) during surgery. Controlled decompression differs from traditional fast direct decompression in that it aims to minimize potential ischemia reperfusion injury and control or mitigate intraoperative acute encephalocele and postoperative cerebral infarction, thereby maximizing the protection of cerebral vascular and nerve function. Our department has used controlled decompression, specifically controlled ventricular drainage and controlled hematoma evacuation, to treat patients with severe traumatic head injury since March 2008. In this report, we describe the findings from a preliminary study comparing outcomes for patients treated with controlled decompressed and patients treated with conventional decompression craniectomy. We hypothesized that patients who received treatment with controlled decompression would have better postoperative outcomes.

\section{METHODS}

\section{Participants}

Patients with severe head injuries who were treated in our hospital from March 2008 to September 2009 were considered for inclusion in the study.

The diagnostic criterion of severe head injury was based on Glasgow Coma Scale (GCS) scores, where a score from 3 to 8 points indicated severe head injury. The inclusion criteria were: (1) A tendency of developing delayed intracranial hematoma. For example, patients with multiple intracranial hematomas or contralateral subdural hematomas, or patients with intracranial hematoma caused by contrecoup injury (with bone fracture at the site of impact) who required craniotomy; (2) Preoperative diffuse brain swelling or local brain swelling; (3) Large volume preoperative hematoma ( $\geq$ $50 \mathrm{~mL}$ ) and obvious compression of the brain tissue (deviation from the midline $>1 \mathrm{~cm}$ ); (4) Extended ( $>2$ hours) unilateral pupil dilation ( $\geq 3 \mathrm{~mm}$ diameter, delayed or no response to light); (5) Bilateral dilated pupils. The exclusion criteria were: (1) Severe multiple injuries (in particular, severe thoracic and abdominal cavity injuries); (2) Definite primary brainstem injury (eg, brainstem hemorrhage); (3) Small intracranial hematoma volume; or (4) A history of severe heart and lung disease.

This study was approved by the Institutional Review Board of 101 Hospital of the Chinese People's Liberation Army.

\section{Study Design}

Consecutive patients with severe head injury were sequentially assigned to receive controlled decompression or conventional decompression ie, the first patient received controlled decompression, the second patient received conventional decompression, the third patient received controlled decompression, and so on. Each group had its own team of physicians comprising one chief physician, two attending physicians, and four resident physicians. Both teams of physicians possessed similar levels of training and experience. Hence, this study comprised a controlled decompression group and a conventional decompression / craniectomy group.

\section{Operative Procedure}

Perioperative procedures were identical for patients in both groups. In addition to routine preoperative preparation, head computed tomography (CT) and head CT angiography examinations were performed on patients whose preoperative conditions allowed these examinations in order to assess changes in cerebral blood vessels and blood flow after trauma. In addition, Codman ICP Express (ICP) monitoring was routinely performed. The duration of preoperative preparation was minimized.

\section{Controlled Decompression}

Before conventional craniotomy and fenestration, a hole was drilled on the line marked for surgical incision. A small incision, of sufficient size to allow insertion of an ICP probe, was then made at the edge of the fenestration of the dura. The ICP probe was inserted and an initial measurement obtained. If the initial ICP was $>40 \mathrm{mmHg}$ (without significant hematoma or evidence of cerebral contusion), a ventricular probe was inserted to gradually release CSF and lower the ICP to $<40$ $\mathrm{mmHg}$. Care was taken to maintain the integrity of the dura before removal of the skull and formation of the bone window. The position of the initial dural incision was selected according to the position and characteristics of the hematoma. For contrecoup injury-related cerebral contusions at the base of the frontal and temporal lobes and subdural hematomas, the dura was incised at the base of the frontal or temporal lobe, parallel to the edge of the fenestration. For other locations, the dura was incised where the hematoma was thickest (in most cases, the origin of bleeding). The dural incision was made in a manner to prevent venous injury. The size of the dural incision was generally no greater than $5 \mathrm{~mm}$, which was often the size of the diameter of the aspirator head. After the dural incision was made, the aspirator head was placed into the incision, the hematoma was partially aspirated, the contused tissue was slowly aspirated, and ICP was gradually 
reduced. The rate of decline in the ICP was 10 to $15 \mathrm{mmHg}$ per $10 \mathrm{~min}$. When the ICP was below $10 \mathrm{mmHg}$, and there were no signs of brain tissue bulging, the dura was completely opened and suspended. The hematoma was then quickly removed and hemostasis was performed as necessary. The skull was closed using standard procedures. During the following surgical process, fluctuations in ICP should be carefully monitored. If the ICP initially decreases before gradually increasing, or gradual bulging of the brain tissue from the fenestration is observed, special attention should be paid for the possible occurrence of delayed hematoma, cerebral infarction, or brain swelling.

\section{Conventional Craniectomy}

Conventional craniectomy was performed using standard operative procedures (12). ICP was released rapidly and completely. Note: patients in this group did not undergo ventricular drainage before craniectomy.

\section{Postoperative Treatment and Monitoring}

Postoperative treatments were the same for patients in both groups. An ICP sensor was routinely used to monitor ICP after surgery (the sensor was typically removed approximately 1 week after surgery). No additional internal decompression was performed after hematoma removal. Hypothermia therapy was performed for 3 to 5 days for patients who had a postoperative GCS score $\leq 5$. Head CT was routinely performed after surgery.

\section{Operative Safety and Postoperative Outcome Assessment}

Operative safety was assessed by comparing the occurrence of delayed hematoma, acute brain swelling, and cerebral infarction between the two groups. Delayed hematoma was indicated when intracranial hematoma was not detected in the initial CT scan, but was detected in a subsequent scan. Acute brain swelling was indicated by brain tissue bulging from the bone defect area because of an acute increase in ICP during surgery. Cerebral infarction, diagnosed by $C T$, was defined as an ischemic brain lesion, which was caused by microcirculation obstruction, cerebral vasospasm, or vascular injury after cranial injury. On CT, cerebral infraction was indicated by abnormal hypodensities in regions of arterial blood supply with clear margins. In contrast, cerebral contusion was indicated by areas of heterogenous densities in the affected region. Where necessary, CT angiography was performed to confirm the diagnosis of cerebral infarction.

Postoperative outcome was assessed by measuring GOS scores 6 months after injury via telephone consultation or face-to-face interview. This scale measures social outcome, which has been defined as the net effect of all separate disabilities on functioning as a person, including dependency on others (9). The severity of disability is rated and classified into the following 5 levels: Good recovery (5): Patients resume normal life and live independently, but mild neurological or pathological defects might be present. Moderate disability (4):
Patientscantakecare of themselves, take publictransportation, do some work, or study in specialized environments or in specialized institutions. Severe disability (3): Patients cannot take care of themselves and require the help of others. They have severe mental and physical disabilities, but they are conscious. Persistent vegetative state (2): Patients are in a long-term coma. They can have opened eyes or peripherally opened eyes. They are awake, but the cerebral cortex has no function, showing a decortical state or decerebrate rigidity. Death (1).

\section{Statistical Analysis}

Quantitative data on patient demographics, clinical outcomes, and safety issues are presented as mean \pm standard deviation for continuous variables and number (\%) for categorical variables. Data for the two treatment groups were compared using independent two-sample t-test for continuous variables and the Chi-square test or Fisher's exact test used for categorical variables. GOS scores were compared by the Mann-Whitney $U$ test. Statistical assessments were considered significant when $p<0.05$. Statistical analyses were performed using SPSS 15.0 statistical software (SPSS Inc, Chicago, IL).

\section{RESULTS}

There were over 320 patients with severe head injuries treated in our hospital from March 2008 to September 2009. A total of 128 patients met the study inclusion criteria and were enrolled in this study. Of these patients 64 (50 men and 14 women) underwent controlled decompression and 64 (58 men and 6 women) underwent decompressive craniotomy.

\section{Demographic and Clinical Data}

The patients' demographics before surgery, the cause of injury, mydriasis status, and the initial GCS score for the two groups were summarized (Table I). The only significant between group difference in these characteristics was in the GCS score; the GCS score was higher in the decompressive craniotomy group compared with the controlled decompression group $(P=0.042)$.

\section{Clinical Outcomes}

There were no significant differences in postoperative ICP or GOS classification between the two groups (Table II). According to the GOS classification, a higher percentage of patients in the controlled decompression group $(53.1 \%$, 34/64) had good recovery compared with patients in the decompressive craniotomy group (35.9\%, 23/64). Twentythree $(35.9 \%)$ patients in the decompressive craniotomy group and $15(23.4 \%)$ patients in the controlled decompression group died during the study.

Figure 1 shows representative examples of pre- and postoperative CT images of one 40-year-old male patient who received controlled decompression. This patient had a deceleration injury with left-sided superacute subdural hematoma and right occipital fracture caused by a right occipital impact force (Figure 1A, B). After the surgery, delayed epidural hema- 
toma was observed initially (red arrows, Figure 1C,D). This did not cause intraoperative acute encephalocele. The ventricular system returned to normal after removal of the right occipital epidural hematoma (Figure 1E, F).

\section{Operative Safety}

The incidence of acute brain swelling was significantly higher in the decompressive craniotomy group compared with the controlled decompression group (Table III, $26.6 \%$ vs $9.4 \%, \mathrm{P}=$ $0.011)$. There were no significant between group differences

Table I: Demographic, Injury, and Clinical Data for 128 Patients with Severe Traumatic Brain Injury Who were Treated with Controlled Decompression or Conventional Decompressive Craniectomy

\begin{tabular}{|l|c|c|c|}
\hline Variable & $\begin{array}{c}\text { Decompressive Craniectomy } \\
(\mathbf{n}=64)\end{array}$ & $\begin{array}{c}\text { Controlled Decompression } \\
(\mathbf{n}=64)\end{array}$ & \begin{tabular}{c}
$p$ value \\
\hline Age, years
\end{tabular} \\
\hline Sex & $41.8 \pm 13.9$ & $44.2 \pm 14.2$ & 0.334 \\
\hline Men & $50(78.1)$ & $58(90.6)$ & 0.051 \\
\hline Women & $14(21.9)$ & $6(9.4)$ & 0.501 \\
\hline Cause of injury & $51(79.7)$ & $48(75.0)$ & \\
\hline Motor vehicle accident & $3(4.7)$ & $3(4.7)$ & \\
\hline Fighting & $0(0)$ & $3(4.7)$ & 1.000 \\
\hline Slips and falls & $10(15.6)$ & $10(15.6)$ & \\
\hline Falls from heights / workplace accidents & $15(23.4)$ & $15(23.4)$ & $17(26.6)$ \\
\hline Mydriasis & $18(28.1)$ & $32(50)$ & \\
\hline No & $31(48.4)$ & $4.8 \pm 1.6$ & $0.042^{*}$ \\
\hline Single side & $5.4 \pm 1.6$ & & \\
\hline Bi-sides & & $23(35.9)$ & 0.710 \\
\hline Initial GCS, score & $21(32.8)$ & $26(40.6)$ & 0.858 \\
\hline Type of intracranial hematoma & $27(42.2)$ & $29(45.3)$ & 0.595 \\
\hline Epidural & $32(50.0)$ & & \\
\hline Subdural & & & \\
\hline Intracerebral & & & \\
\hline
\end{tabular}

GCS, Glasgow Coma Scale.

Continuous data are presented as mean \pm standard deviation and were compared between groups using the two-samplet-test. Categorical data are presented as numbers (\%) and were compared between groups using the Chi-square or Fisher's exact test.

${ }^{a}$ Note: 16 patients in the controlled decompression group and 14 patients in the decompressive craniectomy group had multiple types of hematoma.

*Indicates a statistically significant between groups difference $(P<0.05)$.

Table II: Comparison of Clinical Outcomes Between the Controlled Decompression and Conventional Decompressive Craniectomy Groups

\begin{tabular}{|l|c|c|}
\hline Variable & $\begin{array}{c}\text { Decompressive Craniectomy } \\
(\mathbf{n}=64)\end{array}$ & $\begin{array}{c}\text { Controlled Decompression } \\
(\mathbf{n}=64)\end{array}$ \\
\hline ICP, $\mathrm{mmHg}$ value \\
\hline GOS classification & $45.6 \pm 9.8$ & $45.0 \pm 9.9$ \\
\hline Good recovery & $23(35.9)$ & $34(53.1)$ \\
\hline Moderate disability & $8(12.5)$ & $7(10.9)$ \\
\hline Severe disability & $5(7.8)$ & $4(6.3)$ \\
\hline Vegetative state & $5(7.8)$ & $4(6.3)$ \\
\hline Dead & $23(35.9)$ & $15(23.4)$
\end{tabular}

ICP, intracranial pressure; GOS, Glasgow Outcome Scale.

ICP data are presented as mean \pm standard deviation and were compared between groups using the two-sample t-test. GOS classification data are presented as numbers (\%) and were compared between groups using the Mann-Whitney $U$ test. 
in the incidence of delayed hematoma or postoperative cerebral infarction. The incidence of intraoperative acute encephalocele was $23.1 \%$ among the 13 patients who had delayed hematoma in the controlled decompression group and $61.1 \%$ among the 18 patients who had delayed hematoma in the decompressive craniotomy group. The difference was not statistically significant.

Table III: Comparison of Operative Safety Between the Controlled Decompression and Conventional Decompressive Craniectomy Groups

\begin{tabular}{|l|c|c|c|} 
Symptom & $\begin{array}{c}\text { Decompressive Craniectomy } \\
(\mathbf{n}=64)\end{array}$ & $\begin{array}{c}\text { Controlled Decompression } \\
(\mathbf{n}=64)\end{array}$ & \begin{tabular}{c}
$\boldsymbol{p}$ value \\
\hline Delayed hematoma
\end{tabular} \\
\hline Acute brain swelling & $18(28.1)$ & $13(20.3)$ & 0.302 \\
\hline Cerebral infarction & $17(26.6)$ & $6(9.4)$ & $0.011^{*}$ \\
\hline
\end{tabular}

Data are presented as numbers (\%) and were compared between groups using the Pearson Chi-square test.

* Indicates a statistically significant between groups difference $(P<0.05)$.

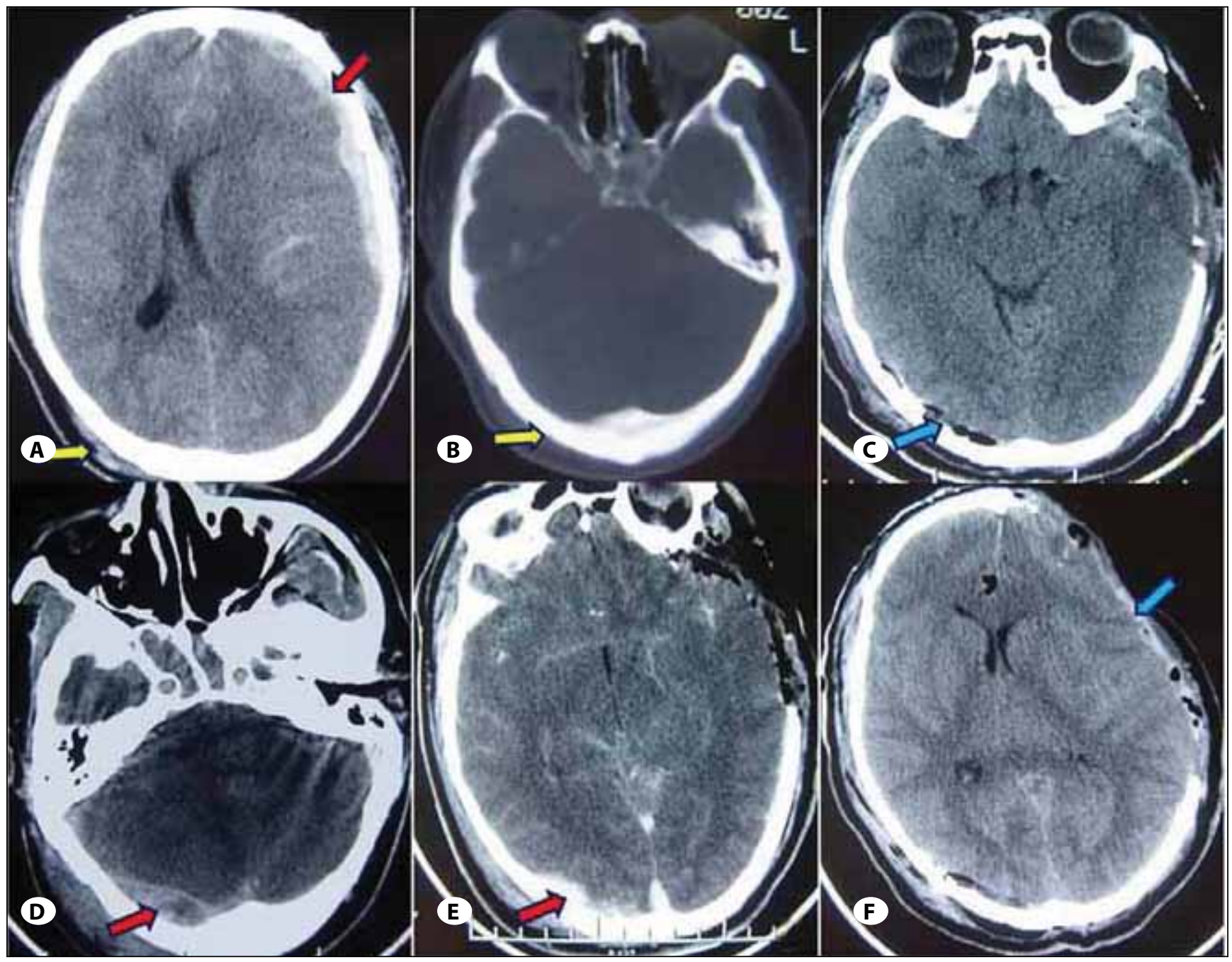

Figure 1: A 40-year-old man was admitted to the hospital with a head injury caused by a fall from a height approximately 1 hour before admission. The patient had bilateral dilated pupils and a Glasgow Coma Scale score of 4. A) Preoperative left-sided superacute subdural hematoma (red arrows). The midline was obviously shifted to the right side. The right occipital area was the point where force was applied (yellow arrow). B) Right occipital fracture (yellow arrow). C, D) A small-sized delayed epidural hematoma was seen at the posterior fossa and in the right occipital area after initial controlled decompression surgery (red arrow). E, F) The ventricular system returned to normal after removal of the right occipital epidural hematoma. Brain tissue collapse at the left-sided fenestration was satisfactory. 


\section{DISCUSSION}

In this preliminary study, we assessed the benefits of controlled decompression surgery for patients with severe head injury. We compared a group of patients who underwent controlled decompression (controlled ventricular drainage and controlled hematoma evacuation) with a group of patients from the same hospital (but different units) who were treated with conventional decompression craniectomy. Our main finding was that the incidence of intraoperative acute brain swelling was significantly lower in the controlled decompression group compared with the conventional decompression craniectomy group, despite the fact that patients in the controlled decompression group had significantly lower preoperative GCS scores (indicating more severe brain damage). We also found that $53.1 \%$ of the patients in the controlled decompression group had a good outcome compared with only $35.9 \%$ in the conventional decompression craniectomy group. Further, $23.4 \%$ of patients in the controlled decompression group died compared with $35.9 \%$ of patients in the conventional decompression craniectomy group.

The proportion of patients in our controlled decompression group who had a good recovery $(53.1 \%)$ is within the range ( $40 \%$ to $71 \%$ ) reported in the literature for patients with severe head injury who were treated with decompression craniectomy $(1,2,4,13)$. The proportion of patients who died in our controlled decompression group (25.4\%) is also within the range $(14 \%$ to $54 \%)$ reported in the literature for decompression craniectomy $(1,2,4,13)$.

There are a variety of causes of intraoperative brain swelling and acute encephalocele, and postoperative cerebral infarction in patients with severe head injury. For example, cerebrovascular regulation disorder may cause diffuse brain swelling, and progressed cerebral contusion may cause deterioration of cerebral edema $(11,15)$. Several cases of contralateral epidural hematoma during decompressive surgery for acute epidural hematomas have been reported $(5,10,11)$. Su et al. described the cases of 12 patients who developed contralateral epidural hematomas after decompressive surgery for acute subdural hematomas (17). In a study performed by Fukamachi et al., 13 of 15 patients who underwent CT within 6 hours of traumatic head injury had extradural hematomas that were not detected until repeat $C T$ examination (6). Based on clinical practice, we believe that rapid decompressionassociated formation of delayed hematoma and diffuse brain swelling are also important causes of intraoperative acute encephalocele $(5,6,10)$. When an intracranial space-occupying hematoma is removed rapidly, we suggest that blood vessels that are not bleeding may rupture and bleed due to the filling pressure effect, thereby resulting in a brain tissue shift. Such a brain tissue shift may snap the blood vessels and aggravate hemorrhage, contributing to a vicious circle of bleeding. In addition, rapid decompression may lead to rapid expansion of compressed cerebral vessels, which in turn may cause reperfusion injury. Controlled decompression may control or mitigate intraoperative acute encephalocele and postoperative cerebral infarction by reducing the incidence of delayed hematoma, alleviating ischemia reperfusion injury, and reducing vascular endothelial injury. These possibilities warrant investigation in future studies.

In our study, the incidence of delayed hematoma was $28.1 \%$ in the decompression craniectomy group and only $20.3 \%$ in the controlled decompression group. Therefore, the incidence in the controlled decompression group was $7.8 \%$ less than that in the decompression craniectomy group. More importantly, intraoperative acute encephalocele only occurred in $23.1 \%$ of patients who experienced delayed hematoma in the controlled decompression group (the corresponding percentage in the decompression craniectomy group was $61.1 \%)$. These encouraging findings suggest that controlled decompression may have helped prevent the development of delayed hematoma, providing valuable time for dealing with hemorrhage at the surgical site and reducing the shift of the brainstem and the incidence of intraoperative acute encephalocele.

We found that the incidence of postoperative cerebral infarction was higher (20.3\%) in the decompression craniectomy group compared with the controlled decompression group (12.5\%). We suggest that this may reflect alleviated ischemic reperfusion injury with controlled decompression and consequent gradual recovery of cerebral blood flow. This difference, however, did not attain statistical significance, perhaps reflecting the relatively small number of patients in the study. Additional studies involving a larger number of patients are needed to confirm and extend our findings.

The main concern with using controlled decompression is whether the speed of decompression is adequate. If the speed of decompression is decreased, the duration of cerebral compression and ischemia will be extended. To address this issue, with placement of a ventricular probe, we reduce ICP by gradually releasing cerebrospinal fluid when the pressure is greater than $40 \mathrm{mmHg}$. In cases where a brain tissue probe is used, we drill the initial hole at the hematoma so that the ICP is gradually reduced with removal of the hematoma. Using these approaches, the speed of ICP reduction with controlled decompression is not affected, and ICP can be reduced as quickly as possible.

Our study is limited by the relatively small number of patients in each group, which reduced statistical power. It must be noted, however, that this was a preliminary study. We suggest that similar, larger scale, better controlled studies are warranted given the encouraging results of our study.

\section{CONCLUSION}

In summary, we found that that the incidence of intraoperative acute brain swelling was significantly lower in patients with severe head injury who received controlled decompression as opposed to conventional decompression craniectomy. Although we were not able to demonstrate statistical significance, a numerically higher proportion of 
patients who received controlled decompression also had good postoperative outcomes. Further, the incidence of acute encephalocele in patients who had delayed hematoma was lower with controlled decompression, as was mortality. Our preliminary findings suggest that controlled decompression, comprising controlled ventricular drainage and controlled hematoma evacuation, may reduce or delay intraoperative acute brain swelling by delaying hematoma formation. Additional studies, involving a larger number of patients, are needed to clarify whether the observed reduction in intraoperative acute brain swelling improves patient prognosis.

\section{ACKNOWLEDGEMENTS}

This work was supported by Nanjing Military Region.

Yuhai Wang and Chunli Wang contributed equally to work.

\section{REFERENCES}

1. Aarabi B, Hesdorffer DC, AhnES, Aresco C, ScaleaTM, Eisenberg HM: Outcome following decompressive craniectomy for malignant swelling due to severe head injury. J Neurosurg 104: 469-479, 2006

2. Bao YH, Liang YM, Gao GY, Pan YH, Luo QZ, Jiang JY: Bilateral decompressive craniectomy for patients with malignant diffuse brain swelling after severe traumatic brain injury: A 37-case study. J Neurotrauma 27:341-347, 2010

3. Dong JR, Jiang JY, Zhu C, Yu MK: The causes and treatment of acute intraoperative encephalocele in severe head injured patients. (A report of 89 cases). Chin J Neurosurg 15: 4-6, 1999 (in Chinese)

4. Eberle BM, Schnüriger B, Inaba K, Gruen JP, Demetriades D, Belzberg H: Decompressive craniectomy: Surgical control of traumatic intracranial hypertension may improve outcome. Injury 41: 894-898, 2010

5. Feuerman T, Wackym PA, Gade GF, Lanman T, Becker D: Intraoperative development of contralateral epidural hematoma during evacuation of traumatic extraaxial hematoma. Neurosurgery 23: 480-484, 1988

6. Fukamachi A, Kohno K, Nagaseki Y, Misumi S, Kunimine $H$, Wakao $\mathrm{T}$ : The incidence of delayed traumatic intracerebral hematoma with extradural hemorrhages. J Trauma 25: $145-149,1985$
7. Huang AP, Tu YK, Tsai YH, Chen YS, Hong WC, Yang CC, Kuo LT, Su IC, Huang SH, Huang SJ: Decompressive craniectomy as the primary surgical intervention for hemorrhagic contusion. J Neurotrauma 25: 1347-1354, 2008

8. Huang $X$, Wen L: Technical considerations in decompressive craniectomy in the treatment of traumatic brain injury. Int J Med Sci 7: 385-390, 2010

9. Jennett B, Snoek J, Bond MR, Brooks N: Disability after severe head injury: Observations on the use of the Glasgow Outcome Scale. J Neurol Neurosurg Psychiatry 44: 285-293, 1981

10. Meguro K, Kobayashi E, Maki Y: Acute brain swelling during evacuation of subdural hematoma caused by delayed contralateral extradural hematoma: Report of two cases. Neurosurgery 20: 326-328, 1987

11. Mohindra S, Mukherjee KK, Gupta R, Chhabra R, Gupta SK, Khosla VK: Decompressive surgery for acute subdural haematoma leading to contralateral extradural haematoma: A report of two cases and review of literature. $\mathrm{Br} J$ Neurosurg 19: 490-494, 2005

12. Münch $E$, Horn $P$, Schürer $L$, Piepgras $A$, Paul T, Schmiedek $P$ : Management of severe traumatic brain injury by decompressive craniectomy. Neurosurgery 47: 315-323, 2000

13. Olivecrona M, Rodling-Wahlstrom M, Naredi S, Koskinen LO: Effective ICP reduction by decompressive craniectomy in patients with severe traumatic brain injury treated by an ICPtargeted therapy. J Neurotrauma 24: 927-935, 2007

14. Piek J: Decompressive surgery in the treatment of traumatic brain injury. Curr Opin Crit Care 8: 134-138, 2002

15. Saito T, Kushi H, Makino K, Hayashi N: The risk factors for the occurrence of acute brain swelling in acute subdural hematoma. Acta Neurochir Suppl 86: 351-354, 2003

16. Sawauchi S, Abe T: The effect of haematoma, brain injury, and secondary insult on brain swelling in traumatic acute subdural haemorrhage. Acta Neurochir (Wien) 150: 531-536, 2008

17. Su TM, Lee TH, Chen WF, Lee TC, Cheng CH: Contralateral acute epidural hematoma after decompressive surgery of acute subdural hematoma: Clinical features and outcome. J Trauma 65:1298-1302, 2008 